\title{
Methylenealkane-Based Low-Viscosity Ester Oils: Synthesis and Outlook
}

\author{
Ilya Nifant'ev ${ }^{1,2, *} \mathbb{0}$, Vladimir Bagrov ${ }^{2}$, Alexander Vinogradov ${ }^{1}$, Alexey Vinogradov ${ }^{1}$, \\ Sergey Ilyin ${ }^{1}\left(\mathbb{D}\right.$, Nadezhda Sevostyanova ${ }^{3}$, Sergey Batashev ${ }^{3}$ and Pavel Ivchenko ${ }^{1,2}$ (]) \\ 1 A.V. Topchiev Institute of Petrochemical Synthesis RAS, 29 Leninsky Pr., 119991 Moscow, Russia; \\ amvvin@mail.ru (A.V.); vinasora@gmail.com (A.V.); s.o.ilyin@gmail.com (S.I.); phpasha1@yandex.ru (P.I.) \\ Chemistry Department, M.V. Lomonosov Moscow State University, 1 Leninskie Gory Str., Building 3, \\ 119991 Moscow, Russia; vlabag@yandex.ru \\ 3 Chemistry Department, Tula State Lev Tolstoy Pedagogical University, 125 Lenin Prospect, 300026 Tula, \\ Russia; piligrim.tula.ru@gmail.com (N.S.); tulapharma@gmail.com (S.B.) \\ * Correspondence: ilnif@yahoo.com; Tel.: +7-495-939-4098
}

Received: 5 March 2020; Accepted: 27 April 2020; Published: 2 May 2020

check for updates

\begin{abstract}
Both Group 4 poly- $\alpha$-olefin (PAO) and Group 5 ester oil basestocks are used in formulations of synthetic engine oils, transmission fluids, and lubricants with leading characteristics such as low viscosity (providing fuel saving), high stability, and environmental safety. The modern technologies of the production of PAOs use catalytic oligomerization of $\alpha$-olefins, which is complicated by the formation of low-molecular-weight $\alpha$-olefin dimers (methylenealkanes) as imminent side products. The use of methylenealkanes as raw materials for the synthesis of Group 5 base stocks appears to be highly promising. In the present work, we report the use of methyl 3-butylnonanoate and methyl 3-hexylundecanoate, the products of catalytic methoxycarbonylation of hex-1-ene and oct-1-ene dimers, in the synthesis of two series of branched isomeric esters. These esters demonstrated excellent rheological behavior and may be considered as low-viscosity engine oils with leading characteristics.
\end{abstract}

Keywords: kinematic viscosity; methoxycarbonylation; methylenealkanes; polyesters; synthetic oils; transesterification

\section{Introduction}

Low-viscosity engine oils, transmission and hydraulic fluids have the potential to substantially increase the energy performance of machines and mechanisms [1-5]. The development of new synthetic approaches to novel types of oils and lubricants with leading characteristics is a relevant task of applied chemistry [6]. The objective requirements for these materials are, in particular, the ability to flow at sub-zero temperatures, maintaining lubrication properties at elevated temperatures, low volatility, as well as high chemical and thermal stability [7]. During the operation of combustion engines, up to half of the motor oil enters the environment, and it is therefore desirable for high-quality oils and lubricants to be biodegradable and non-toxic materials [8].

These actual requirements define two main pathways in the development of the modern oils. The first approach is based on efficient utilization of renewable sources such as vegetable oil, biomass, etc. In this case, the possible imperfection in the product characteristics is compensated by the availability and low price of the raw materials [8-22]. The second approach uses the rational design of the molecular structure of the oil base stocks $[23,24]$ - this is the direction taken by the leading chemical companies in the development of Group 4 poly- $\alpha$-olefin oils (PAOs). The modern PAOs are hydrogenated $\alpha$-olefin oligomers and produced in two stages by metallocene-catalyzed oligomerization of $\alpha$-olefins followed by the catalytic hydrogenation of structurally uniform oligomers 
(Scheme 1) [25-31]. However, the first stage of this process is accompanied by the formation of $\alpha$-olefin dimers-methylenealkanes [25,32-37]—using a highly efficient heterocene catalyst [31].

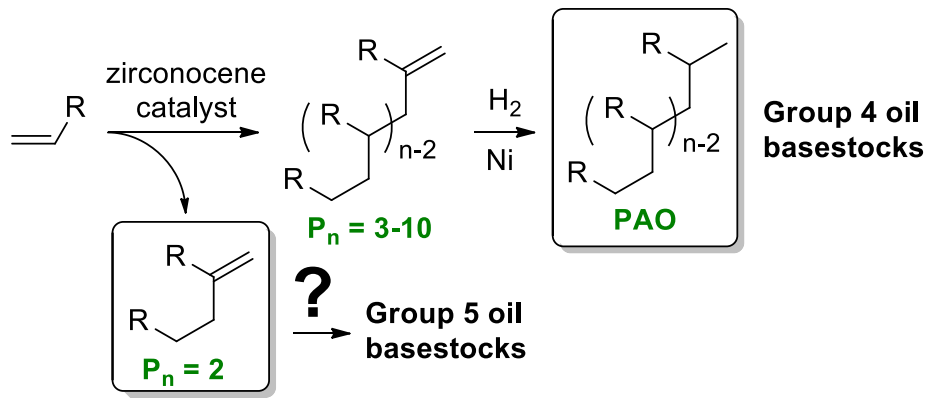

Scheme 1. The modern synthesis of Group 4 oil basestocks and the problem of methylenealkanes.

Therefore, the problem of the utilization of methylenealkanes that are unavoidable by-products of $\alpha$-olefin oligomerization is of great relevance and importance. In view of the fact that high-quality engine oils contain both Group 4 and Group 5 base stocks, the idea of using these methylenealkanes in the production of Group 5 oils is economically attractive.

The branched structure of methylenealkanes offers hope for superior viscosity characteristics of their derivatives, for example, esters. The prospects of structurally-similar Guerbet alcohols in the synthesis of the Group 5 oils have been demonstrated earlier [38-40]. Thus, the synthetic approach to obtain homologs of these alcohols using methylenealkanes seems to be highly prospective, bearing in mind only moderate product yields in the dimerization of 1-alkanols according to a Guerbet reaction [41,42] (Scheme 2a). The synthesis of branched alcohols from methylenealkanes via hydroformylation with subsequent reduction was performed earlier by Patil et al. (Exxon) $[43,44]$ and by Kashiwamura et al. (Idemitsu) [45]. These alcohols were used in the synthesis of branched esters with promising viscosity characteristics (Scheme 2b).
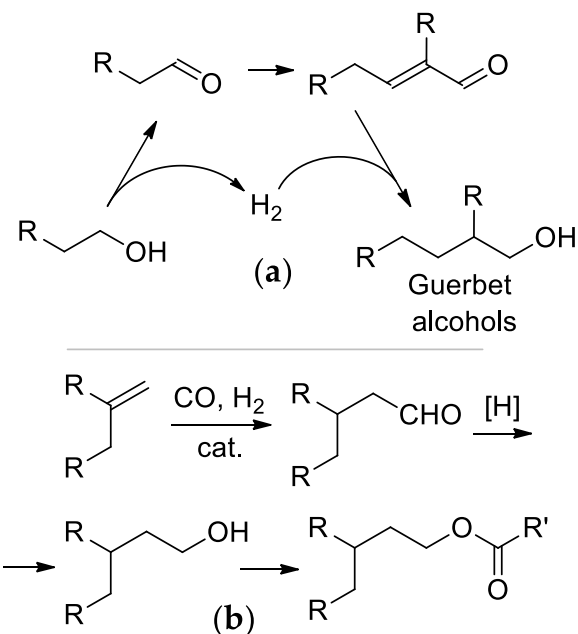

(b)<smiles>[R]COC(=O)CC([R])C[R]</smiles>

(c)

Scheme 2. (a) Synthesis of Guerbet alcohols; (b) Hydroformylalion of methylenealkanes followed by reduction and esterification [43-45]; (c) Methoxycarbonylation of methylenealkanes followed by preparation of isomeric esters (this work).

Recently [46], we reported an efficient method of catalytic methoxycarbonylation of methylenealkanes with regioselective formation of the corresponding methyl esters (Scheme 2c). In contrast with the hydroformylation/reduction sequence reported earlier [43-45] (Scheme 2b), our approach (Scheme 2c) allows obtaining the esters that contain methylenealkane-derived branched alkyl in acid or in alcohol fragment ot the molecule. In that way, we can synthesize isomeric esters in 
order to establish the molecular structure that provides the best viscosity characteristics. In the present paper, we report the preliminary results on the synthesis and comparative study of the esters based on 5-methyleneundecane and 7-methylenepentadecane (dimers of hex-1-ene and oct-1-ene) as prospective Group 5 base oils.

\section{Materials and Methods}

\subsection{General Experimental Remarks}

Triisobutylaluminium (TIBA, 1 M solution in hexane, Merck, Kenilworth, NJ, USA), modified methylalumoxane (MMAO-12, $1.52 \mathrm{M}$ solution in toluene, Merck), and $\mathrm{CDCl}_{3}\left(99.8 \%{ }^{2} \mathrm{H}\right.$, Cambridge Isotope Laboratories Inc., Tewksbury, MA, USA) were used as purchased. Oct-1-ene (Merck) was stored over $\mathrm{Na}$ wire and distilled under argon. Toluene and $o$-xylene were refluxed over $\mathrm{Na} / \mathrm{benzophenone}$ and distilled before use. Methanol (Merck) was dried over $\mathrm{CaO}$ and distilled under argon. Hydrogen (99.999\%, Linde Gas Rus, Balashikha, Russia) was used without purification.

Diphosphine ligand 2,3-bis((diphenylphosphino)methyl)bicyclo[2.2.1]heptane (trans-isomer) [47], 2-ethylhexanoyl chloride [48], 5-methyleneundecane, 7-methylenepentadecane [49] and hydrogenated trimers of oct-1-ene and dec-1-ene [31] were synthesized according to previously reported procedures.

The ${ }^{1} \mathrm{H}$ NMR spectra were recorded on a Bruker AVANCE 400 spectrometer $(400 \mathrm{MHz}$, Bruker, Billerica, MS, USA) at $20^{\circ} \mathrm{C}$. The chemical shifts are reported in ppm relative to the solvent residual peaks. GC analysis was carried out with a Crystallux-4000M chromatograph with a flame ionization detector (Meta-Chrom Ltd, Yoshkar-Ola, Russia). Analysis was carried out using 30,000 $\times 0.32 \mathrm{~mm}$ fused silica columns with stationary phase poly[methyl(95)phenyl(5)] siloxane (film thickness $0.25 \mu \mathrm{m}$ ) at a carrier gas (argon) flow rate of $1 \mathrm{~mL} / \mathrm{min}$, split ratio 1:50, detector and injection port temperature of $300{ }^{\circ} \mathrm{C}$ in the isothermal mode of $150{ }^{\circ} \mathrm{C}$. Injection volume was $0.4 \mu \mathrm{L}$. The chromatographic peaks of the reactants, isomeric alkenes, and products were identified based on their retention times, and the content of each component was determined by GC of artificial mixtures of known concentrations. Elemental analysis (C, H, N, O) was performed using a Perkin Elmer Series II CHNS/O Analyzer 2400 (Perkin Elmer, Waltham, MA, USA).

\subsection{Methoxycarbonylation of Methylenealkanes}

The diamagnetic steel autoclave with thermostated jacket was equipped with magnetic stirrer and separate $\mathrm{CO}$ and $\mathrm{H}_{2}$ high-pressure lines. The reaction temperature was monitored by a precalibrated Chromel-Copel thermocouple. A constant temperature was maintained with an accuracy of $\pm 0.5^{\circ} \mathrm{C}$ by circulating a high-temperature bath fluid (polydimethylsiloxane) through the reactor jacket. The autoclave pressure was measured by a standard pressure gauge attached to the lid. All experiments were carried out with a stirrer rotation speed of $600 \mathrm{rpm}$.

A mixture of methylenealkane $(60 \mathrm{mmol})$, methanol (3.88 mL, $96 \mathrm{mmol}), o$-xylene $(1 \mathrm{~mL}), \mathrm{PdCl}_{2}$ $(0.6 \mathrm{mmol})$, diphosphine $(1.32 \mathrm{mmol})$ and toluene (added to the total volume of $200 \mathrm{~mL})$ was placed in an autoclave. The autoclave was purged three times with $5 \times 10^{5} \mathrm{~Pa}$ of $\mathrm{CO}$ and then pressurized to $1 \times 10^{6} \mathrm{~Pa}$ at room temperature. The autoclave was heated to $115^{\circ} \mathrm{C}$, and the pressure was increased to $2 \times 10^{6} \mathrm{~Pa}$ by $\mathrm{CO}$ feed, then to $2.6 \times 10^{6} \mathrm{~Pa}$ by hydrogen feed and finally to $3.2 \times 10^{6} \mathrm{~Pa}$ by $\mathrm{CO}$ feed. The constant pressure was maintained by $\mathrm{CO}$ feed. After $20 \mathrm{~h}$, the autoclave was cooled to room temperature and vented. The reaction mixture was filtered, evaporated under reduced pressure, and the residue was distilled in vacuo. Boiling points and isolated yields of the esters are given below, while NMR spectra are presented in Supplementary Figures S1 and S2.

Methyl 3-butylnonanoate: B. p. $89-91{ }^{\circ} \mathrm{C}$ (1 Torr). The yield was $11.1 \mathrm{~g}(81 \%)$. Elemental Analysis: for $\mathrm{C}_{14} \mathrm{H}_{28} \mathrm{O}_{2}$ Calc., \%: C, 73.63; H, 12.36; O, 14.01. Found, \%: C, 73.69; $\mathrm{H}, 12.37 ; \mathrm{O}, 13.94 .{ }^{1} \mathrm{H}$ NMR $\left(\mathrm{CDCl}_{3}, 400 \mathrm{MHz}, 2{ }^{\circ} \mathrm{C}\right) \delta: 3.65(\mathrm{~s}, 3 \mathrm{H}) ; 2.22\left(\mathrm{~d},{ }^{3} \mathrm{~J}=6.8 \mathrm{~Hz}, 2 \mathrm{H}\right) ; 1.83(\mathrm{br}, 1 \mathrm{H}) ; 1.28(\mathrm{br}, 16 \mathrm{H}) ; 0.873$ $\left(\mathrm{t},{ }^{3} \mathrm{~J}=6.8 \mathrm{~Hz}, 3 \mathrm{H}\right) ; 0.867\left(\mathrm{t},{ }^{3} \mathrm{~J}=6.8 \mathrm{~Hz}, 3 \mathrm{H}\right)$. 
Methyl 3-hexylundecanoate (E1): B. p. $95-97^{\circ} \mathrm{C}(0.1$ Torr). The yield was $12.9 \mathrm{~g}(76 \%)$. Elemental Analysis: for $\mathrm{C}_{18} \mathrm{H}_{36} \mathrm{O}_{2}$ Calc., \%: C, 76.00; $\mathrm{H}, 12.75 ; \mathrm{O}, 11.25$. Found, \%: $\mathrm{C}, 76.04 ; \mathrm{H}, 12.80 ; \mathrm{O}, 11.16 .{ }^{1} \mathrm{H}$ $\operatorname{NMR}\left(\mathrm{CDCl}_{3}, 400 \mathrm{MHz}, 20^{\circ} \mathrm{C}\right) \delta: 3.65(\mathrm{~s}, 3 \mathrm{H}) ; 2.23\left(\mathrm{~d},{ }^{3} \mathrm{~J}=6.8 \mathrm{~Hz}, 2 \mathrm{H}\right) ; 1.83(\mathrm{br}, 1 \mathrm{H}) ; 1.25($ broad, $24 \mathrm{H})$; $0.87\left(\mathrm{t},{ }^{3} \mathrm{~J}=6.7 \mathrm{~Hz}, 6 \mathrm{H}\right)$.

\subsection{Synthesis of Branched Alcohols and Esters E2-E5}

\subsubsection{3-Butylnonan-1-ol}

Methyl 3-butylnonanoate $(11.4 \mathrm{~g}, 50 \mathrm{mmol})$ in $\mathrm{Et}_{2} \mathrm{O}(25 \mathrm{~mL})$ was added dropwise to cooled $\left(0^{\circ} \mathrm{C}\right)$ suspension of $\mathrm{LiAlH}_{4}(1.14 \mathrm{~g}, 30 \mathrm{mmol})$ in $\mathrm{Et}_{2} \mathrm{O}(200 \mathrm{~mL})$. The mixture was allowed warming to room temperature, stirred for $1 \mathrm{~h}$, cooled to $0{ }^{\circ} \mathrm{C}$, and $5 \%$ aq. solution of $\mathrm{NaF}(50 \mathrm{~mL})$ was added. Organic phase was separated, dried over $\mathrm{MgSO}_{4}$, evaporated and distilled in vacuo, b.p. $88-90{ }^{\circ} \mathrm{C}$ at 0.5 Torr. The yield was $8.2 \mathrm{~g}(82 \%)$, colorless liquid. Elemental analysis: for $\mathrm{C}_{13} \mathrm{H}_{28} \mathrm{O}$ Calc., \%: C, 77.93; $\mathrm{H}, 14.09$; $\mathrm{O}$, 7.99. Found, \%: C, 77.90; $\mathrm{H}, 14.13 ; \mathrm{O}, 7.97 .{ }^{1} \mathrm{H} \mathrm{NMR}\left(\mathrm{CDCl}_{3}, 400 \mathrm{MHz}, 20{ }^{\circ} \mathrm{C}\right) \delta: 3.62(\mathrm{t}, 2 \mathrm{H}) ; 1.57$ (bs, 1H); 1.51 (q, 2H); 1.40 (br, 1H); 1.25 (bs, 16H); $0.87(\mathrm{t}, 6 \mathrm{H})$.

\subsubsection{3-Hexylundecan-1-ol}

This compound was obtained by the same manner from methyl 3-hexylundecanoate (14.2 $\mathrm{g}$, $50 \mathrm{mmol})$. B.p. $120-123^{\circ} \mathrm{C}$ at 0.5 Torr. The yield was $10.8 \mathrm{~g}(84 \%)$, colorless liquid. Elemental analysis: for $\mathrm{C}_{17} \mathrm{H}_{36} \mathrm{O}$ Calc., \%: C, 79.61; $\mathrm{H}, 14.15 ; \mathrm{O}, 6.24$. Found, \%: C, 79.70; $\mathrm{H}, 14.18 ; \mathrm{O}, 6.12 .{ }^{1} \mathrm{H} \mathrm{NMR}\left(\mathrm{CDCl}_{3}\right.$, $\left.400 \mathrm{MHz}, 20^{\circ} \mathrm{C}\right) \delta: 3.64(\mathrm{t}, 2 \mathrm{H}) ; 1.62(\mathrm{br}, 1 \mathrm{H}) ; 1.51(\mathrm{q}, 2 \mathrm{H}) ; 1.40(\mathrm{br}, 1 \mathrm{H}) ; 1.24(\mathrm{bs}, 24 \mathrm{H}) ; 0.87(\mathrm{t}, 6 \mathrm{H})$.

\subsubsection{3-Butylnonyl 2-ethylhexanoate (E2)}

2-Ethylhexanoyl chloride $(3.25 \mathrm{~g}, 20 \mathrm{mmol})$ was added dropwise at $0{ }^{\circ} \mathrm{C}$ to the solution of 3-butylnonan-1-ol (3.73 g, $20 \mathrm{mmol})$ and pyridine $(1.6 \mathrm{~mL}, 20 \mathrm{mmol})$ in dry $\mathrm{CHCl}_{3}(50 \mathrm{~mL})$. After $12 \mathrm{~h}$ of stirring at room temperature, the mixture was poured into ice water/ $\mathrm{HCl}(50 / 10 \mathrm{~mL})$, organic phase was separated, aqueous phase was extracted by $\mathrm{CHCl}_{3}$. Combined organic fractions were washed by brine, dried over $\mathrm{MgSO}_{4}$ and evaporated under reduced pressure. The residue was distilled in vacuo, b.p. $130-132{ }^{\circ} \mathrm{C}$ at 0.51 Torr. The yield was $5.06 \mathrm{~g}(81 \%)$, colorless liquid. Elemental analysis: for $\mathrm{C}_{21} \mathrm{H}_{42} \mathrm{O}_{2}$ Calc., \%: C, 77.24; $\mathrm{H}, 12.96$; O, 9.80. Found, \%: C, 77.30; $\mathrm{H}, 12.98 ; \mathrm{O}, 9.72 .{ }^{1} \mathrm{H}$ NMR $\left(\mathrm{CDCl}_{3}, 400 \mathrm{MHz}, 20^{\circ} \mathrm{C}\right) \delta: 4.09(\mathrm{t}, 2 \mathrm{H}) ; 2.23(\mathrm{~m}, 1 \mathrm{H}) ; 1.56(\mathrm{q}, 2 \mathrm{H}) ; 1.42(\mathrm{~m}, 1 \mathrm{H}) ; 1.25(\mathrm{br}, 24 \mathrm{H}) ; 0.90-0.85$ (gr. t, 12H).

\subsubsection{3-Hexylundecyl 2-ethylhexanoate (E3)}

This compound was obtained by the same manner from 3-hexylundecan-1-ol (4.85 g, $20 \mathrm{mmol})$. B.p. $170-172{ }^{\circ} \mathrm{C}$ at 0.5 Torr. The yield was $5.68 \mathrm{~g}(77 \%)$, colorless liquid. Elemental analysis: for $\mathrm{C}_{25} \mathrm{H}_{50} \mathrm{O}_{2}$ Calc., \%: $\mathrm{C}, 78.47 ; \mathrm{H}, 13.17 ; \mathrm{O}, 8.36$. Found, \%: $\mathrm{C}, 78.50 ; \mathrm{H}, 13.22 ; \mathrm{O}, 8.28 .{ }^{1} \mathrm{H} \mathrm{NMR}\left(\mathrm{CDCl}_{3}\right.$, $\left.400 \mathrm{MHz}, 20{ }^{\circ} \mathrm{C}\right) \delta: 4.09(\mathrm{t}, 2 \mathrm{H}) ; 2.23(\mathrm{~m}, 1 \mathrm{H}) ; 1.56(\mathrm{q}, 2 \mathrm{H}) ; 1.45(\mathrm{~m}, 1 \mathrm{H}) ; 1.25(\mathrm{br}, 36 \mathrm{H}) ; 0.90-0.85$ (gr. t, 12H).

\subsubsection{Octyl 3-hexylundecanoate (E4)}

Sodium methoxide $(0.11 \mathrm{~g}, 2 \mathrm{mmol})$ was added to stirred mixture of methyl 3-hexylundecanoate $(5.4 \mathrm{~g}, 20 \mathrm{mmol})$ and octan-1-ol $(11.6 \mathrm{~g}, 100 \mathrm{mmol})$. After $10 \mathrm{~h}$ of heating to $100{ }^{\circ} \mathrm{C}$ the mixture was cooled, $\mathrm{H}_{2} \mathrm{O}(10 \mathrm{~mL})$ was added. The mixture was extracted by $n$-hexane $(520 \mathrm{~mL})$, combined organic fractions were dried over $\mathrm{MgSO}_{4}$ and evaporated under reduced pressure. The residue was distilled in vacuo, b.p. $175-177^{\circ} \mathrm{C}$ at 0.5 Torr. The yield was $4.9 \mathrm{~g}(66 \%)$, colorless liquid. Elemental analysis: for $\mathrm{C}_{25} \mathrm{H}_{50} \mathrm{O}_{2}$ Calc., \%: C, 78.47; $\mathrm{H}, 13.17 ; \mathrm{O}, 8.36$. Found, \%: C, 78.50; $\mathrm{H}, 13.20 ; \mathrm{O}, 8.30 .{ }^{1} \mathrm{H}$ NMR $\left(\mathrm{CDCl}_{3}\right.$, $\left.400 \mathrm{MHz}, 20^{\circ} \mathrm{C}\right) \delta: 4.05(\mathrm{t}, 2 \mathrm{H}) ; 2.21(\mathrm{~d}, 2 \mathrm{H}) ; 1.83(\mathrm{~m}, 1 \mathrm{H}) ; 1.61(\mathrm{~m}, 2 \mathrm{H}) ; 1.25(\mathrm{br}, 34 \mathrm{H}) ; 0.87(\mathrm{t}, 9 \mathrm{H})$. 


\subsubsection{2-Ethylhexyl 3-hexylundecanoate (E5)}

This compound was obtained by the same manner from methyl 3-hexylundecanoate $(5.4 \mathrm{~g}$, $20 \mathrm{mmol})$ and 2-ethylhexan-1-ol (11.6 g, $100 \mathrm{mmol})$. B.p. $170-172{ }^{\circ} \mathrm{C}$ at 0.5 Torr. The yield was $5.1 \mathrm{~g}$ (69\%), colorless liquid. Elemental Analysis: for $\mathrm{C}_{25} \mathrm{H}_{50} \mathrm{O}_{2}$ Calc., \%: C, 78.47; H, 13.17; O, 8.36. Found, \%: C, 78.55; H, 13.26; O, 8.19. ${ }^{1} \mathrm{H}$ NMR $\left(\mathrm{CDCl}_{3}, 400 \mathrm{MHz}, 20{ }^{\circ} \mathrm{C}\right) \delta: 3.97(\mathrm{dd}, 2 \mathrm{H}) ; 2.22(\mathrm{~d}, 2 \mathrm{H}) ; 1.83$ (m, 1H); 1.55 (m, 1H); 1.25 (br, 32H); 0.90-0.85 (gr. t, 12H).

NMR spectra are presented in Supplementary Figures S3-S8.

\subsection{Viscosity Measurements}

Viscosity properties of the samples of prospective oil base stocks were studied using rotational rheometer DHR-2 (TA Instruments, New Castle, DE, USA) with cone-plate geometry (cone diameter $40 \mathrm{~mm}$, cone/plate angle $2^{\circ}$ ). Viscosity-temperature correlations were obtained with the temperature change rate of $5{ }^{\circ} \mathrm{C} / \mathrm{min}$ and constant shear stresses of 1 and $100 \mathrm{~Pa}$ for temperatures above and below $25^{\circ} \mathrm{C}$, respectively.

\section{Results}

\subsection{Synthesis of Branched Esters}

Synthetic routes used for the synthesis of branched alcohols and esters E1-E5 are presented in Scheme 3. The reduction of methyl 3-butylnonanoate and methyl 3-hexylundecanoate resulted in the corresponding branched alcohols with more than $80 \%$ isolated yields. Branched esters E2 and E3 were obtained by the reaction of these alcohols with 2-ethylhexanoyl chloride. Esters E4 and E5 were obtained by transesterification of the methyl ester E1 with octan-1-ol and 2-ethylhexan-1-ol, respectively. Sodium methoxide was used as a catalyst of transesterification. Branched alcohols and esters E2-E5 were separated by distillation in vacuo without thermal degradation and isomerization.

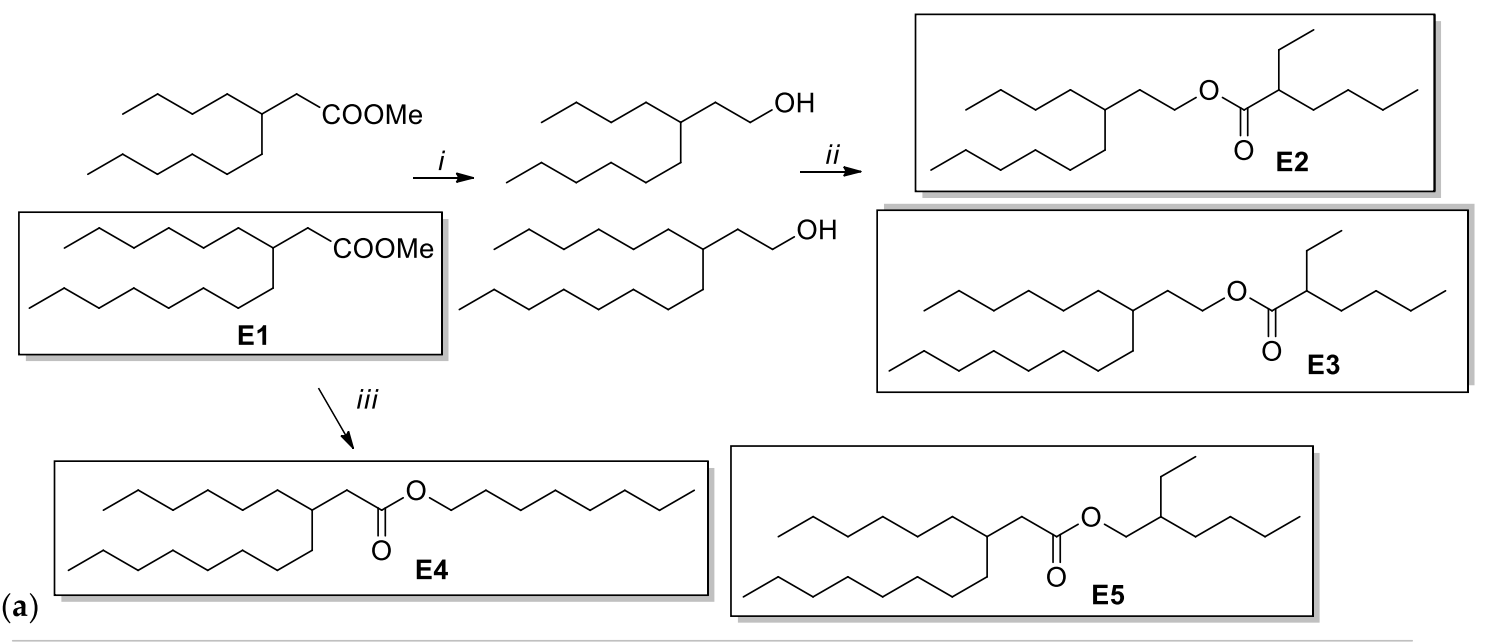

(b)

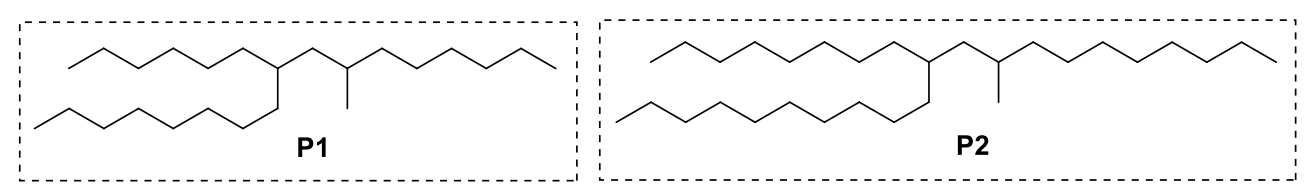

Scheme 3. (a) Synthesis of branched alcohols and branched esters, (i) $\mathrm{LiAlH}_{4} / \mathrm{Et}_{2} \mathrm{O}$, then hydrolysis; (ii) 2-ethylhexanoyl chloride, pyridine, $\mathrm{CHCl}_{3}$; (iii) 1-octanol or 2-ethylhexanol, $\mathrm{NaOMe}, 100{ }^{\circ} \mathrm{C}$;

(b) Low-viscosity PAO basestocks that were used as a benchmark. 


\subsection{Viscosity of Branched Esters}

Viscosity of the esters obtained was studied for the compounds E1-E5 (see Scheme 3, selected by the frames). Methyl 3-butylnonanoate was excluded from our selection as unimportant for lubrication use due to its low viscosity at $100{ }^{\circ} \mathrm{C}(0.98 \mathrm{cSt})$. For comparison, we also studied hydrogenated trimers of oct-1-ene and dec-1-ene (P1 and P2, respectively) as Group 4 oil base stocks with close molecular weights.

The viscosity index (VI) is a commonly used characteristic of base oils and lubricants that reflects the abilities of the oil to flow at low temperatures and to keep lubrication properties at elevated temperatures. However, VI is not applicable for low-viscosity oils. In addition, the temperature interval for the determination of VI is $0-100{ }^{\circ} \mathrm{C}$, which does not fully cover the operating temperatures of machineries. The pour point is another characteristic of base oils that is essential for the estimation of their applicability at sub-zero temperatures. Nevertheless, even these two characteristics, supplemented with the data on the viscosity at $-40{ }^{\circ} \mathrm{C}$, do not represent the full picture of the viscosity-temperature relationships. In our study, we have measured and analyzed the viscosities of E1-E5, P1 and P2 in the temperature interval from -60 to $150{ }^{\circ} \mathrm{C}$ (Figure 1 ).

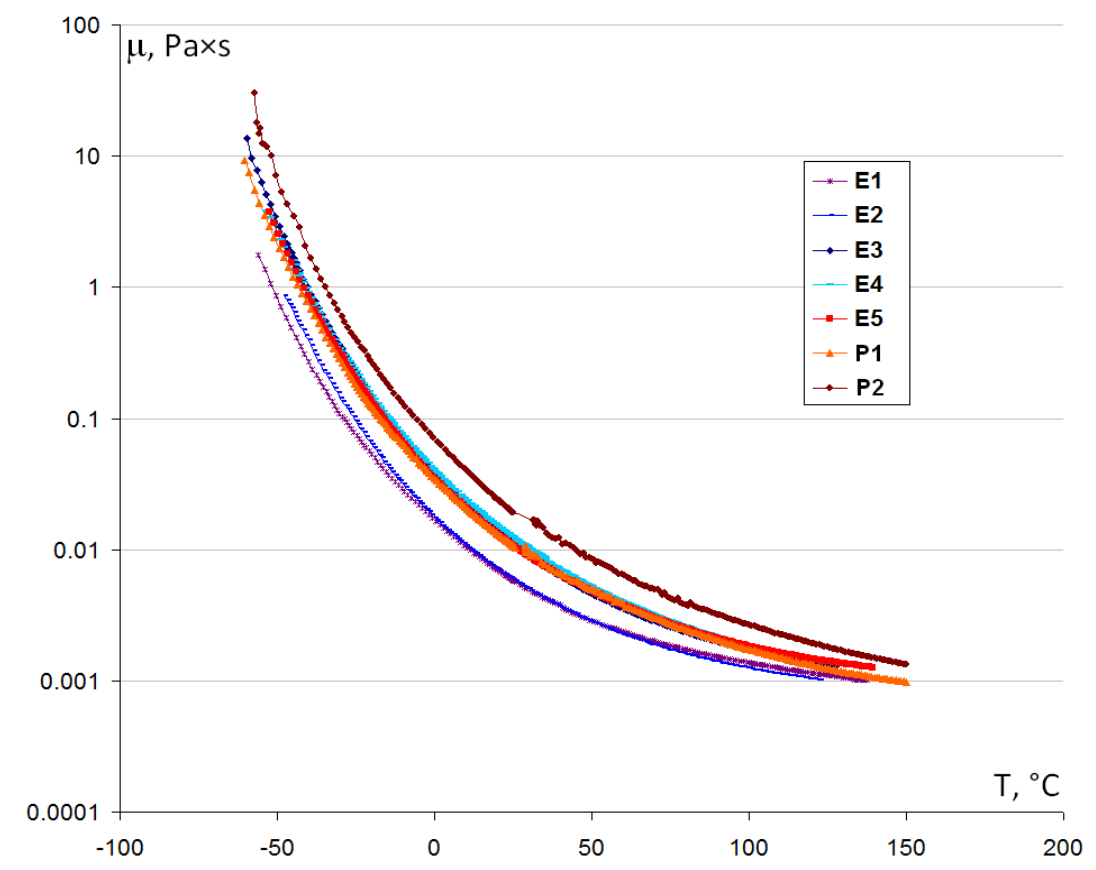

Figure 1. The temperature dependence of the dynamic viscosity for E1-E5, P1 and P2.

The common empirical temperature-viscosity correlation is a two-parameter exponential known as an Andrade Equation (1) [50].

$$
\mu=A e^{\frac{E_{a}}{R T}}, \text { or } \ln \mu=\ln A+\frac{E_{a}}{R T}
$$

where $\mu$ is dynamic viscosity, $A$ is an empirical parameter, $R$ is the gas constant, $T$ is temperature, and $E_{a}$ is a viscosity activation energy.

This Arrhenius-like correlation is not applicable for the temperatures near the glass transition point. Given the importance of the viscosity of base oils at both high and low temperatures, Equation (2) could be proposed.

$$
\ln \mu=\frac{T \ln \mu_{T \rightarrow \infty}+\frac{E_{a}^{\prime}}{R}}{T-T_{\mu \rightarrow \infty}}
$$


This equation is based on assumptions about the constant viscosity at high temperatures $(T \rightarrow \infty)$ and infinitely high viscosity $(\mu \rightarrow \infty)$ at a low temperature that is close to glass transition point. If $T>T_{\mu \rightarrow \infty}$, Equation (2) becomes the Andrade Equation (1). The results of the approximations of the experimental data on the thermal dependences of dynamic viscosities of E1-E5, P1 and P2 by Equation (2) are presented in Table 1. Note that such an approximation was in good agreement with the experimental results $\left(R^{2}>0.999\right)$.

Table 1. The key experimental and calculated (Equations (1) and (2)) characteristics of E1-E5, P1 and P2.

\begin{tabular}{|c|c|c|c|c|c|c|c|c|c|}
\hline \multirow{2}{*}{$\begin{array}{c}\text { Oil } \\
\text { Basestock }\end{array}$} & \multicolumn{4}{|c|}{ Dynamic Viscosity, at $T\left({ }^{\circ} \mathrm{C}\right), \mathrm{mPa} \cdot \mathrm{s}$} & \multirow{2}{*}{$\begin{array}{c}\text { Pour } \\
\text { Point, }{ }^{\circ} \mathrm{C}\end{array}$} & \multirow{2}{*}{$\begin{array}{c}E_{\mathrm{a},}{ }^{1} \\
\mathrm{~kJ} / \mathrm{mol}\end{array}$} & \multirow{2}{*}{$\begin{array}{c}E_{\mathrm{a},}^{\prime}{ }^{2} \\
\mathrm{~kJ} / \mathrm{mol}\end{array}$} & \multirow{2}{*}{$T_{\substack{\mu \rightarrow \infty \\
{ }^{\circ} \mathrm{C}}}{ }^{2}$} & \multirow{2}{*}{$\begin{array}{c}\mu_{T \rightarrow \infty,}{ }^{2} \\
\text { mPa.s }\end{array}$} \\
\hline & -40 & 25 & 40 & 100 & & & & & \\
\hline E1 & 267 & 5.86 & 3.75 & 1.38 & -58 & 15.7 & 17.5 & -116.3 & 0.076 \\
\hline E2 & 392 & 5.93 & 3.67 & 1.25 & -56 & 17.6 & 18.4 & -114.2 & 0.056 \\
\hline E3 & 893 & 11.5 & 6.28 & 1.73 & -60 & 20.7 & 20.3 & -130.4 & 0.027 \\
\hline E4 & 910 & 12.4 & 7.16 & 1.88 & -53 & 21.4 & 20.1 & -134.2 & 0.029 \\
\hline E5 & 852 & 10.9 & 6.41 & 1.83 & -60 & 20.3 & 19.2 & -125.7 & 0.045 \\
\hline P1 & 725 & 10.7 & 6.57 & 1.75 & -62 & 19.1 & 19.6 & -132.6 & 0.034 \\
\hline P2 & 1850 & 19.2 & 11.7 & 2.67 & -57 & 21.4 & 20.0 & -129.8 & 0.041 \\
\hline
\end{tabular}

${ }^{1}$ Based on experimental data for temperature interval $40-120{ }^{\circ} \mathrm{C}$, Equation $(1) ;{ }^{2}$ Calculated parameters of the Equation (2).

\section{Discussion}

The value of $\mu_{T \rightarrow \infty}$, which can be interpreted as a viscosity at the temperature close to the boiling point, correlates to the volatility of the compound under study: it may be assumed that, all other things being equal, the lower this viscosity, the higher the boiling point and therefore the lower the evaporation rate. The pour point of base oils is close to a temperature of their either crystallization or glass transition depending on their nature and ability to crystallize. In the first case, the oils lose their fluidity instantly [51], while in the second one, it happens gradually when the viscosity reaches about 500-1000 Pa.s [52]. $T_{\mu \rightarrow \infty}$ should correlate with glass transition temperature. In our case, $T_{\mu \rightarrow \infty}$ is far below the pour point; in addition, viscosity at a temperature slightly below the pour point is $1-30 \mathrm{~Pa} \cdot \mathrm{s}$. Thus, the loss of fluidity of ester oils and hydrogenated $\alpha$-olefin trimers is due to their crystallization. This means that there is potential for lowering the pour point of these oils (down to $\left.-(80-100){ }^{\circ} \mathrm{C}\right)$ by optimizing their structure or introduction of additives that inhibit crystallization.

A few other important observations and findings could be drawn from the data presented in Table 1. Methyl ester E1 is characterized by low viscosity at $100{ }^{\circ} \mathrm{C}$ and potentially high volatility, and therefore could hardly be regarded as a base stock of the engine oil. The same is true for the derivative of hex-1-ene dimer, 3-butylnonyl 2-ethylhexanoate E2: this compound with higher molecular weight in comparison with $\mathbf{E 1}$ is characterized by higher viscosity at $-40{ }^{\circ} \mathrm{C}$ and lower viscosity at $100{ }^{\circ} \mathrm{C}$. The derivatives of oct-1-ene dimer E3-E5 seem to be substantially more promising oil base stocks, bearing in mind the characteristics of high-quality Group 4 oil benchmarks P1 and P2. The esters E3-E5 have equal molecular weight, and the comparison of their viscosity characteristics may allow us to find optimal type of the molecular structure of the promising Group 5 basestock based on $\alpha$-olefin dimer.

Among these three esters, compound E5 has the minimal low-temperature viscosity and satisfactory value of the dynamic viscosity at $100{ }^{\circ} \mathrm{C}$. The efficient viscosity activation energy $E^{\prime}{ }_{\mathrm{a}}$ for $\mathbf{E} 5$ was also lowest among the basestocks under study. Taking into account the low value of the pour point, E5 can be regarded as a prospective prototype for the further design of the formulation of Group 5 ester oils based on by-products of the synthesis of Group 4 poly- $\alpha$-olefin oils.

The global task of the energy efficiency and saving within the context of the machine's exploitation will require the consideration of both viscosity reduction and oil drain interval extension [5]. Minimization of the environmental pollution should also be taken into account [4]. In this regard, the development of efficient synthetic approaches to Group 5 oil basestocks appears to be a promising area of the advanced applied chemistry. The utilization of $\alpha$-olefin dimers, which are by-products of 
the modern Group 4 oil technology, with the obtaining of Group 5 oil basestocks that are not inferior in their characteristics to the best PAO oils, seem to us evidence-based and economically beneficial. We therefore hope that the results of our preliminary study could contribute to development of the modern non-waste $\alpha$-olefin-based technologies of engine oils and lubricants.

Supplementary Materials: The following are available online at http://www.mdpi.com/2075-4442/8/5/50/s1, Figures S1-S8: NMR spectra of the branched esters and alcohols, Tables S1-S7: the data on temperature dependence of dynamic viscosity for E1-E5, P1 and P2.

Author Contributions: Conceptualization, I.N., S.I. and P.I.; methodology, S.I.; software, S.I.; validation, S.I. and Alexey V.; formal analysis, S.I.; investigation, V.B., A.V. (Alexander Vinogradov), A.V. (Alexey Vinogradov) and S.I., N.S. and S.B.; resources, S.I.; data curation, S.I.; writing-original draft preparation, P.I.; writing-review and editing, S.I. and P.I.; visualization, P.I.; supervision, I.N.; project administration, A.V. (Alexander Vinogradov); funding acquisition, A.V. (Alexander Vinogradov). All authors have read and agreed to the published version of the manuscript.

Funding: This research was funded by the Russian Science Foundation, grant number 18-73-10128, and partially supported by the TIPS RAS plan (experimental study of the viscosity of branched esters and reference oils).

Conflicts of Interest: The authors declare no conflict of interest. The funders had no role in the design of the study; in the collection, analyses, or interpretation of data; in the writing of the manuscript, and in the decision to publish the results.

\section{References}

1. Atabani, A.E.; Badruddin, I.A.; Mekhilef, S.; Silitonga, A.S. A review on global fuel economy standards, labels and technologies in the transportation sector. Renew. Sustain. Energy Rev. 2011, 15, 4586-4610. [CrossRef]

2. Zhang, X.A.; Zhao, Y.; Ma, K.; Wang, Q. Friction behavior and wear protection ability of selected base lubricants. Friction 2016, 4, 72-83. [CrossRef]

3. Hope, K. PAO Contributions to Energy Efficiency in 0W-20 Passenger Car Engine Oils. Lubricants 2018, 6, 73. [CrossRef]

4. Maroto-Centeno, J.-A.; Pérez-Gutiérrez, T.; Fernández-Ruíz-Morón, L.; Quesada-Pérez, M. Prediction of fuel economy performance of engine lubricants based on laboratory bench tests. Tribol. Int. 2016, 94, 67-70. [CrossRef]

5. Ishizaki, K.; Nakano, M. Reduction of $\mathrm{CO}_{2}$ Emissions and Cost Analysis of Ultra-Low Viscosity Engine Oil. Lubricants 2018, 6, 102. [CrossRef]

6. Ray, S.; Rao, P.V.C.; Choudary, N.V. Poly- $\alpha$-olefin-based synthetic lubricants: A short review on various synthetic routes. Lubric. Sci. 2012, 24, 23-44. [CrossRef]

7. Tripathi, A.K.; Vinu, R. Characterization of Thermal Stability of Synthetic and Semi-Synthetic Engine Oils. Lubricants 2015, 3, 54-79. [CrossRef]

8. Ho, C.K.; McAuley, K.B.; Peppley, B.A. Biolubricants through renewable hydrocarbons: A perspective for new opportunities. Renew. Sustain. Energy Rev. 2019, 113, 109261. [CrossRef]

9. Willing, A. Lubricants based on renewable resources-An environmentally compatible alternative to mineral oil products. Chemosphere 2001, 43, 89-98. [CrossRef]

10. Kodali, D.R. High performance ester lubricants from natural oils. Ind. Lubr. Tribol. 2002, 54, $165-170$. [CrossRef]

11. Adhvaryu, A.; Erhan, S.Z.; Perez, J.M. Tribological studies of thermally and chemically modified vegetable oils for use as environmentally friendly lubricants. Wear 2004, 257, 359-367. [CrossRef]

12. Schneider, M.P. Plant-oil-based lubricants and hydraulic fluids. J. Sci. Food. Agric. 2006, 86, 1769-1780. [CrossRef]

13. Shylesh, S.; Gokhale, A.A.; Ho, C.R.; Bell, A.T. Novel Strategies for the Production of Fuels, Lubricants, and Chemicals from Biomass. Acc. Chem. Res. 2017, 50, 2589-2597. [CrossRef] [PubMed]

14. Salimon, J.; Salih, N.; Yousif, E. Biolubricants: Raw materials, chemical modifications and environmental benefits. Eur. J. Lipid Sci. Technol. 2010, 112, 519-530. [CrossRef]

15. Kannan, K.T.; Rameshbabu, S. Tribological properties of modified jojoba oil as probable base stoke of engine lubricant. J. Mech. Sci. Technol. 2018, 32, 1739-1747. [CrossRef]

16. Nagendramma, P.; Kaul, S. Development of ecofriendly/biodegradable lubricants: An overview. Renew. Sustain. Energy Rev. 2012, 16, 764-774. [CrossRef] 
17. Mobarak, H.M.; Mohamad, E.N.; Masjuki, H.H.; Kalam, M.A.; Al Mahmud, K.A.H.; Habibullah, M.; Ashraful, A.M. The prospects of biolubricants as alternatives in automotive applications. Renew. Sustain. Energy Rev. 2014, 33, 34-43. [CrossRef]

18. Syahir, A.Z.; Zulkifli, N.W.M.; Masjuki, H.H.; Kalam, M.A.; Alabdulkarem, A.; Gulzar, M.; Khuong, L.S.; Harith, M.H. A review on bio-based lubricants and their applications. J. Clean. Prod. 2017, 168, 997-1016. [CrossRef]

19. Mannekote, J.K.; Kailas, S.V.; Venkatesh, K.; Kathyayini, N. Environmentally friendly functional fluids from renewable and sustainable sources-A review. Renew. Sustain. Energy Rev. 2018, 81, 1787-1801. [CrossRef]

20. Zainal, N.A.; Zulkifli, N.W.M.; Gulzar, M.; Masjuki, H.H. A review on the chemistry, production, and technological potential of bio-based lubricants. Renew. Sustain. Energy Rev. 2018, 82, 80-102. [CrossRef]

21. Chan, C.-H.; Tang, S.W.; Mohd, N.K.; Lim, W.H.; Yeong, S.K.; Idris, Z. Tribological behavior of biolubricant base stocks and additives. Renew. Sustain. Energy Rev. 2018, 93, 145-157. [CrossRef]

22. Rorrer, J.E.; Bell, A.T.; Toste, F.D. Synthesis of Biomass-Derived Ethers for Use as Fuels and Lubricants. ChemSusChem 2019, 12, 2835-2858. [CrossRef] [PubMed]

23. Kioupis, L.I.; Maginn, E.J. Molecular Simulation of Poly- $\alpha$-olefin Synthetic Lubricants? Impact of Molecular Architecture on Performance Properties. J. Phys. Chem. B 1999, 103, 10781-10790. [CrossRef]

24. Reeves, C.J.; Siddaiah, A.; Menezes, P.L. A Review on the Science and Technology of Natural and Synthetic Biolubricants. J. Bio Tribo Corros. 2017, 3, 11. [CrossRef]

25. DiMaio, A.J. Process for the Oligmerization of Alpha-Olefins Having Low. Unsaturation. Patent US7129306, 31 November 2006.

26. Patil, A.O.; Bodige, S.; Luo, S.; Chu, J.W.; Stavens, K.; Harrrington, B.A. Ultra High Viscosity Synthetic Base Stocks and Process for Preparing Same. U.S. Patent Application US2014213834, 31 July 2014.

27. Small, B.L.; Hope, K.D.; Masino, A.P.; McDaniel, M.P.; Buck, R.M.; Beaulieu, W.B.; Yang, Q.; Baralt, E.J.; Netemeyer, E.J.; Kreischer, B. Oligomerization of Alpha Olefins Using Metallocene-SSA Catalyst Systems and Use of the Resultant Polyalphaolefins to Prepare Lubricant Blends. Patent US8536391, 17 September 2013.

28. Hagemeister, M.P.; Jiang, P.; Wu, M.M.; Yang, N. Production of Shear-Stable High Viscosity PAO. Patent US9365663, 14 June 2016.

29. Wu, M.M.; Coker, C.L.; Walzer, J.F.; Jiang, P.; Rucker, S.P. Process to Produce High Viscosity Fluids. Patent US7989670, 2 August 2011.

30. Park, J.H.; Jang, Y.E.; Jeon, J.Y.; Go, M.J.; Lee, J.; Kim, S.K.; Lee, S.-I.; Lee, B.Y. Preparation of ansa-metallocenes for production of poly ( $\alpha$-olefin) lubricants. Dalton Trans. 2014, 43, 10132-10138. [CrossRef]

31. Nifant'ev, I.E.; Vinogradov, A.A.; Vinogradov, A.A.; Sedov, I.V.; Dorokhov, V.G.; Lyadov, A.S.; Ivchenko, P.V. Structurally uniform 1-hexene, 1-octene, and 1-decene oligomers: Zirconocene/MAO-catalyzed preparation, characterization, and prospects of their use as low-viscosity low-temperature oil base stocks. Appl. Catal. A Gen. 2018, 549, 40-50. [CrossRef]

32. Janiak, C.; Lange, K.C.H.; Marquardt, P. Alkyl-substituted cyclopentadienyl- and phospholyl-zirconium/MAO catalysts for propene and 1-hexene oligomerization. J. Mol. Catal. A Chem. 2002, 180, 43-58. [CrossRef]

33. Janiak, C.; Lange, K.C.H.; Marquardt, P.; Krüger, R.-P.; Hanselmann, R. Analyses of Propene and 1-Hexene Oligomers from Zirconocene/MAO Catalysts-Mechanistic Implications by NMR, SEC, and MALDI-TOF MS. Macromol. Chem. Phys. 2002, 203, 129-138. [CrossRef]

34. Fujikawa, S.; Yokota, K.; Okano, M.; Tsuji, M. Method for Producing $\alpha$-Olefin Oligomers and Lubricating Oil Compositions. Patent Application US2011207977, 25 July 2011.

35. Welle, A.; Wassenaar, J.; Slawinski, M. Use of a Metallocene Catalyst to Produce a Polyalpha-Olefin. Patent US9688792, 27 June 2017.

36. Wu, M.M.; Coker, C.L.; Walzer, J.F.; Jiang, P. Process to Produce Low Viscosity Poly-Alfa-Olefins. Patent US8207390, 26 June 2012.

37. Nifant'ev, I.E.; Vinogradov, A.A.; Vinogradov, A.A.; Bezzubov, S.I.; Ivchenko, P.V. Catalytic oligomerization of $\alpha$-olefins in the presence of two-stage activated zirconocene catalyst based on 6,6-dimethylfulvene 'dimer'. Mendeleev Commun. 2017, 27, 35-37. [CrossRef]

38. Gabriëls, D.; Hernández, W.Y.; Sels, B.; Van Der Voort, P.; Verberckmoes, A. Review of catalytic systems and thermodynamics for the Guerbet condensation reaction and challenges for biomass valorization. Catal. Sci. Technol. 2015, 5, 3876-3902. [CrossRef] 
39. Knothe, G. Characterization of esters of fatty acids and dicarboxylic acids with Guerbet alcohols. J. Am. Oil Chem. Soc. 2001, 78, 537-540. [CrossRef]

40. Waykole, C.; Bhowmick, D.N.; Pratap, A. Synthetic Base Stock Based on Guerbet Alcohols. J. Am. Oil Chem. Soc. 2014, 91, 1407-1416. [CrossRef]

41. Matsu-ura, T.; Sakaguchi, S.; Obora, Y.; Ishii, Y. Guerbet Reaction of Primary Alcohols Leading to $\beta$-Alkylated Dimer Alcohols Catalyzed by Iridium Complexes. J. Org. Chem. 2006, 71, 8306-8308. [CrossRef] [PubMed]

42. Goulas, K.A.; Sreekumar, S.; Song, Y.; Kharidehal, P.; Gunbas, G.; Dietrich, P.J.; Johnson, G.R.; Wang, Y.C.; Grippo, A.M.; Grabow, L.C.; et al. Synergistic Effects in Bimetallic Palladium-Copper Catalysts Improve Selectivity in Oxygenate Coupling Reactions. J. Am. Chem. Soc. 2016, 138, 6805-6812. [CrossRef]

43. Ng, M.K.; Oumar-Mahamat, H.; Cheng, H.; Blain, D.A.; Cooper, K.K.; Carey, J.T.; Douglass, M.R.; Kanga, P.R.; Patil, A.O.; Bodige, S.; et al. Low Viscosity Low Volatility Lubricating Oil Base Stocks and Methods of Use Thereof. Patent US10077409, 18 September 2018.

44. Patil, A.; Lewis, K.G.; Bodige, S.; Zushma, S. Ester Compounds, Lubricating Oil Composition Containing Same and Process for Making Same. Patent Application US2019062663, 28 February 2019.

45. Sato, H.; Kashiwamura, T.; Okamoto, T.; Yokota, K. Carbonyl Compound Containing Long-Chain Branched Alkyl Group. Patent US7402610, 22 July 2008.

46. Nafant'ev, I.E.; Sevostyanova, N.T.; Batashev, S.A.; Vinogradov, A.A.; Vinogradov, A.A.; Churakov, A.V.; Ivchenko, P.V. Synthesis of methyl $\beta$-alkylcarboxylates by Pd/diphosphine-catalyzed methoxycarbonylation of methylenealkanes $\mathrm{RCH}_{2} \mathrm{CH}_{2} \mathrm{C}(\mathrm{R})=\mathrm{CH}_{2}$. Appl. Catal. A Gen. 2019, 581, 123-132. [CrossRef]

47. Hayashi, T.; Kawabata, Y.; Isoyama, T.; Ogata, I. Platinum Chloride-Diphosphine-Tin(II) Halide Systems as Active and Selective Hydroformylation Catalysts. Bull. Chem. Soc. Jpn. 1981, 54, 3438-3446. [CrossRef]

48. Sulzbacher, M.; Bergmann, E. Synthesis of $p$-alkylstyrenes. J. Org. Chem. 1948, 13, 303-308. [CrossRef]

49. Nifant'ev, I.E.; Vinogradov, A.A.; Vinogradov, A.A.; Ivchenko, P.V. Zirconocene-catalyzed dimerization of 1-hexene: Two-stage activation and structure-catalytic performance relationship. Catal. Commun. 2016, 79, 6-10. [CrossRef]

50. Dienes, G.J. Activation Energy for Viscous Flow and Short-Range Order. J. Appl. Phys. 1953, $24,779-782$. [CrossRef]

51. Ilyin, S.O.; Arinina, M.P.; Polyakova, M.Y.; Kulichikhin, V.G.; Malkin, A.Y. Rheological comparison of light and heavy crude oils. Fuel 2016, 186, 157-167. [CrossRef]

52. Ilyin, S.O.; Strelets, L.A. Basic Fundamentals of Petroleum Rheology and Their Application for the Investigation of Crude Oils of Different Natures. Energy Fuels 2018, 32, 268-278. [CrossRef] 